Florida International University FIU Digital Commons

\title{
Temporal variation in dwarf sperm whale (Kogia sima) habitat use and group size off Great Abaco Island, the Bahamas
}

Meagan Mná Dunphy-Daly

Florida International University

DOI: $10.25148 /$ etd.FI15101248

Follow this and additional works at: https://digitalcommons.fiu.edu/etd

Part of the Biology Commons, and the Marine Biology Commons

\section{Recommended Citation}

Dunphy-Daly, Meagan Mná, "Temporal variation in dwarf sperm whale (Kogia sima) habitat use and group size off Great Abaco Island, the Bahamas" (2008). FIU Electronic Theses and Dissertations. 3101.

https://digitalcommons.fiu.edu/etd/3101 
FLORIDA INTERNATIONAL UNIVERSITY

Miami, Florida

TEMPORAL VARIATION IN DWARF SPERM WHALE (KOGIA SIMA) HABITAT USE AND GROUP SIZE OFF GREAT ABACO ISLAND, THE BAHAMAS

A thesis submitted in partial fulfillment of the

requirements for the degree of

MASTER OF SCIENCE

in

BIOLOGY

by

Meagan Mná Dunphy-Daly

2008 
To: Dean Kenneth Furton

College of Arts and Sciences

This thesis, written by Meagan Mná Dunphy-Daly, and entitled Temporal Variation in Dwarf Sperm Whale (Kogia sima) Habitat Use and Group Size off Great Abaco Island, the Bahamas, having been approved in respect to style and intellectual content, is referred to you for judgment.

We have read this thesis and recommend that it be approved.

Maureen Donnelly

Douglas Wartzok

Michael Heithaus, Major Professor

Date of Defense: July 11, 2008

The thesis of Meagan Mná Dunphy-Daly is approved.

Dean Kenneth Furton College of Arts and Sciences

Dean George Walker University Graduate School

Florida International University, 2008 
(C) Copyright 2008 by Meagan Mná Dunphy-Daly

All rights reserved. 


\section{DEDICATION}

I dedicate this thesis to my parents. They have inspired me to become the person and scientist that I am today. Their endless support, love, encouragement, and belief in me made the completion of this research possible. 


\section{ACKNOWLEDGMENTS}

I would like to begin by thanking my major professor, Dr. Michael Heithaus, for his optimism, support, and confidence in my research. He never doubted my abilities and encouraged me throughout each step of this process. Diane Claridge welcomed me to her home and research site in Sandy Point and without her generosity and help this thesis would not have existed. I wish to thank the additional members of my committee, Dr. Maureen Donnelly and Dr. Douglas Wartzok, for their support and suggestions throughout my research and writing. Dr. John Durban also kindly provided advice and comments on a previous version of this manuscript.

I am grateful for the Earthwatch Institute volunteers and Bahamas Marine Mammal Research Organisation (BMMRO) scientific staff and research assistants that helped with data collection from 2000-2006 and made this project possible. I also would like to thank the members of my lab, particularly Derek Burkholder and Aaron Wirsing, for their advice, suggestions, proofreading skills, and friendship throughout my research. I am especially grateful to Jason Somarelli for his encouragement and support during my time in the Bahamas and while writing my thesis in Miami. Finally, I would like to thank my family for their love and their support of all of my adventures.

This research was funded by an NSF Graduate Research Fellowship, Earthwatch Institute, SeaSpace, Florida International University Judith Evans Parker Travel Scholarship, and Florida International University College of Arts and Sciences. Photographs in this thesis are courtesy of BMMRO. 


\section{ABSTRACT OF THE THESIS \\ TEMPORAL VARIATION IN DWARF SPERM WHALE (KOGIA SIMA) HABITAT USE AND GROUP SIZE OFF GREAT ABACO ISLAND, THE BAHAMAS by}

\section{Meagan Mná Dunphy-Daly}

Florida International University, 2008

Miami, Florida

Professor Michael Heithaus, Major Professor

Dwarf sperm whales, Kogia sima, are among the most commonly stranded yet least known pelagic cetaceans. I assessed seasonal and spatial variation in dwarf sperm whale group size and abundance off Great Abaco Island, the Bahamas. After correcting for survey effort and variation in sighting efficiency among sea states, I found that dwarf sperm whale group size and habitat use varied seasonally. In summer, dwarf sperm whale groups were small $($ median $=2.5$, range $=1-8)$ and were found only in the two deep habitats within the study area (slope 400-900 m, deep 900-1600 m). In winter, group sizes increased (median $=4$, range $=1-12$ ) and sightings were almost six times higher in the slope habitat, where vertical relief is highest, than other habitats. My results suggest that studies of pelagic cetaceans and conservation plans must explicitly account for seasonal variation in group size and habitat use. 


\section{TABLE OF CONTENTS}

CHAPTER

PAGE

PREFACE

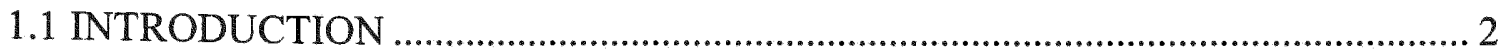

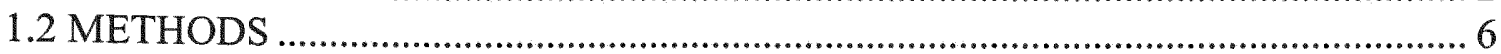

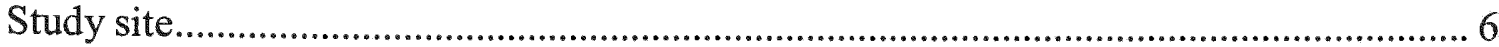

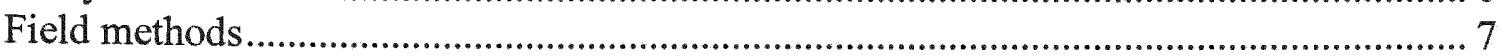

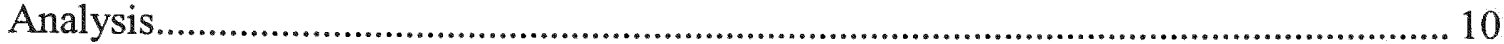

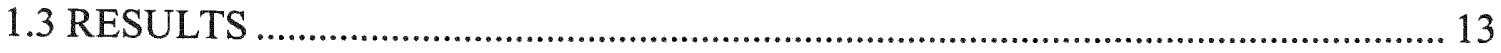

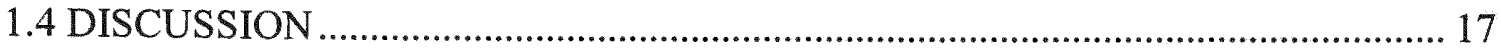

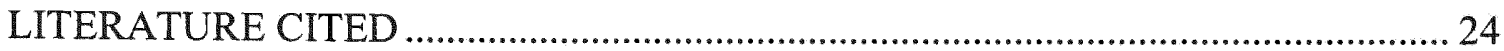




\section{LIST OF FIGURES}

FIGURE

PAGE

1. Dwarf sperm whale and pygmy sperm whale dorsal fins ..........................4

2. Location of the study off Great Abaco Island, the Bahamas ..............................6

3. The $6 \times 21 \mathrm{~km}$ study area off southern Great Abaco Island ..........................

4. Two examples of randomized zigzag survey tracks ..............................8

5. The study area with $100 \mathrm{~m}$ bathymetric contours and dwarf sperm whale sightings ...10

6. Examples of identifiable and unidentifiable dwarf sperm whale dorsal fins ...........13

7. Spatial and temporal variation in dwarf sperm whale sightings per unit effort ........16

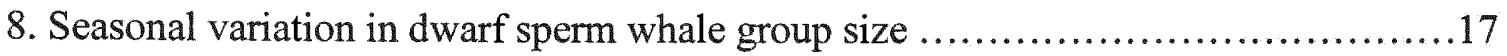

9. Killer whale attack on a dwarf sperm whale in the study area ......................21 


\section{PREFACE}

A version of this thesis appears as:

Dunphy-Daly, M.M., M.R. Heithaus, and D.E. Claridge. 2008. Temporal variation in dwarf sperm whale (Kogia sima) habitat use and group size off Great Abaco Island, Bahamas. Marine Mammal Science 24: 171-182. 


\subsection{INTRODUCTION}

Increases in strandings of deep-diving cetaceans have generated considerable interest in poorly-known pelagic species. Of particular concern is minimizing anthropogenic effects, like noise and fishery interactions, which appear to be responsible for some strandings (e.g., Frantzis 1998, Balcomb and Claridge 2001, CardonnaMaldonado and Mignucci-Giannoni 1999, Jepson et al. 2003, Fernández et al. 2005). For example, seventeen cetaceans (including beaked whales species, minke whales, Balaenoptera acutorstrata, and spotted dolphins, Stenella frontalis) stranded in the Bahamas during active sonar exercises by naval ships in 2000 (see Balcomb and Claridge 2001) and at least 12 Cuvier's beaked whales (Ziphius cavirostris) stranded in the Mediterranean Sea during North Atlantic Treaty Organization (NATO) tests with low frequency active sonar in 1996 (Frantzis 1998). Fishery-induced mortality of pelagic cetaceans also is of considerable concern. In the United States, populations of deep diving species, such as Cuvier's beaked whales, Mesoplodon beaked whales (Mesoplodon sp.), short-finned pilot whales (Globicephala macrorhynchus), and sperm whales (Physeter macrocephalus) are vulnerable to fishery mortality (Read and Wade 2000). Data on the impact of fishery interactions do not exist for many other deep-diving species.

In light of these anthropogenic impacts to pelagic cetaceans, studies of their habitat use and seasonal changes in their distribution and abundance are important for identifying places where, and times when, anthropogenic impacts are likely to be greatest. Although beaked whales have received considerable attention (e.g., Barlow and 
Gisner 2006, MacLeod and D'Amico 2006), few studies have focused on dwarf sperm whales (Kogia sima) which are one of the most commonly stranded deep-diving cetaceans in temperate and tropical areas (Cardona-Maldonado and Mignucci-Giannoni 1999).

Dwarf sperm whales inhabit warm temperate and tropical waters and occur along the continental shelf and slope (see Willis and Baird 1998). In many locations, dwarf sperm whales are sympatric with pygmy sperm whales, Kogia breviceps. Both species of Kogia have a robust body and a discreet underslung jaw and are counter-shaded. Kogia are unique among marine mammals in that they have a sac within their lower intestine that is filled with dense, dark fluid (Caldwell and Caldwell 1989) that can be expelled in a dense cloud that may be a defense mechanism similar to that employed by squids (e.g., Caldwell et al. 1971).

Dwarf sperm whales are distinguished from pygmy sperm whales mainly by the size and position of their dorsal fin (see Willis and Baird 1998; Figure 1). The base height of the dorsal fin of dwarf sperm whales is greater than $5 \%$ of the total body length, whereas pygmy sperm whale dorsal fins are shorter and are less than $5 \%$ of the total body length (Willis and Baird 1998, McAlpine 2002). Furthermore, in dwarf sperm whales the dorsal fin is positioned more anteriorally than the dorsal fin of pygmy sperm whales (Willis and Baird 1998). Adult dwarf sperm whales can reach $2.7 \mathrm{~m}$ in length and can weigh between 136 and $272 \mathrm{~kg}$ (Handley 1966, Ross 1978). The larger pygmy sperm whale can grow to $4.25 \mathrm{~m}$ and $408 \mathrm{~kg}$ (Caldwell et al. 1971). 


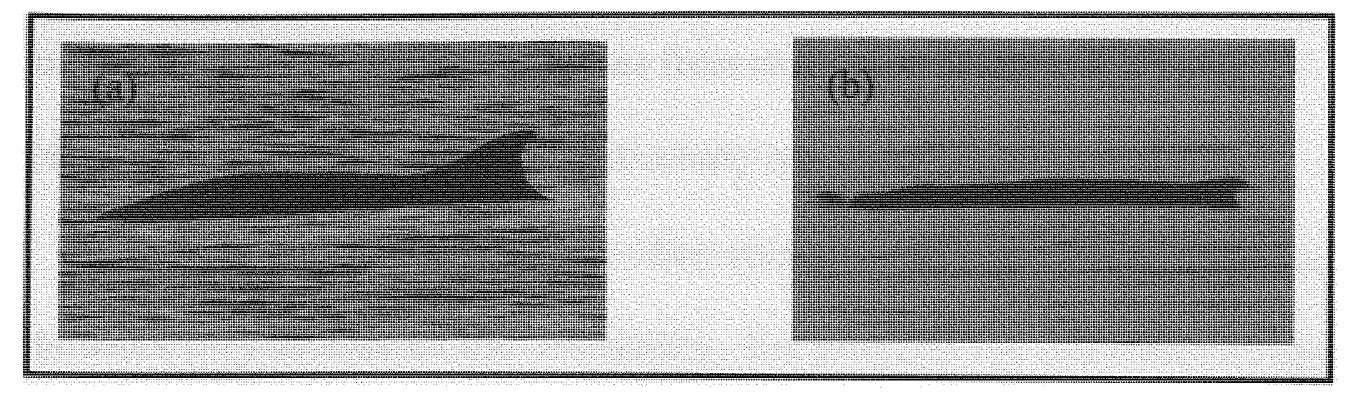

Figure 1: Dwarf sperm whale (a) and pygmy sperm whale (b) dorsal fins

Most of what we know about dwarf sperm whales comes from stranded animals Stranded animals commonly are entangled in gillnets (due to fisheries interactions), have experienced watercraft collisions, or have helminth loads in the esophagus and stomach, intestinal blockage, cardiomyopathy, or hemorrhage in the lungs, kidneys, spleen, and heart (Cardona-Maldonado and Mignucci-Giannoni 1999, Manire et al. 2004).

Stomach contents from stranded animals suggest that they feed primarily on cephalopods and, to a lesser extent, on crustaceans and fish (see Nagorsen 1985, Willis and Baird 1998, Cardona-Maldonado and Mignucci-Giannoni 1999). Squid remains in stranded dwarf sperm whale stomachs represent over 15 different families of squid (see Willis and Baird 1998 for citations). It has been suggested that dwarf sperm whales feed on smaller squid and at shallower depths than pygmy sperm whales, although their diets overlap (see Willis and Baird 1998).

Despite frequent strandings in temperate and tropical locations (CardonaMaldonado and Mignucci-Giannoni 1999), dwarf sperm whales are rarely identified at sea (Willis and Baird 1998, Baird 2005), probably because of their offshore habitat, small adult size (2.0-2.7 m), tendency to rest motionless at the surface, long dive durations, and propensity to avoid close approaches by boats (Willis and Baird 1998). Since most 
information on dwarf sperm whales comes from strandings, studies of this species' distribution and abundance at sea are particularly important.

Pelagic cetacean distributions are often correlated with bathymetric features that may influence prey abundance and availability. For example, the abundance of Risso's dolphin (Grampus griseus) is highest in depths of 200-1000 $\mathrm{m}$ along the steep upper continental slope (Baumgartner et al. 2001), humpback whale (Megaptera novaeangliae) and minke whale distributions off Antarctica are correlated with high bathymetric slope and high prey abundance (Friedlaender et al. 2006), and deep water and relatively steep topographic features appear to be preferred by northern bottlenose whales (Hyperoodon ampullatus) (Hooker et al. 2002). Habitat use and abundance of pelagic cetaceans also may vary seasonally. For example, when faced with seasonal food shortages, sperm whales often migrate hundreds of kilometers, resulting in seasonal and inter-annual variation in their abundance (Whitehead 1996, Jaquet et al. 2000).

Oceanic islands provide an opportunity to study elusive pelagic species, such as dwarf sperm whales, because of access to deep water using small, shore-based vessels (e.g., Baird 2005). Great Abaco Island, in the northeast Bahamas, is ideal for studies of dwarf sperm whales because it sits upon a shallow carbonate bank that rapidly drops off to deep canyons, providing easy access for small research vessels. The objectives of this study were to 1) determine whether dwarf sperm whale relative abundance varied temporally and spatially off Great Abaco Island, and 2) compare group sizes of dwarf sperm whales across habitats, seasons, and years. 


\subsection{METHODS}

\section{Study site}

The study was conducted off Great Abaco Island, in the northeast Bahamas ( $c a$. $25^{\circ} 55.0^{\prime} \mathrm{N}, 77^{\circ} 20.0^{\prime} \mathrm{W}$, Figure 2) where the deep waters of the Northwest Providence Channel, a branch of the Great Bahama Canyon, lie within $3 \mathrm{~km}$ of shore. A $6 \times 21 \mathrm{~km}$ study grid, running parallel to shore and covering depths between 2-1600 m (Figure 3), has been the focus of long-term cetacean monitoring by the Bahamas Marine Mammal Research Organisation (BMMRO) since 1997. Within this area, average sea surface temperatures generally are below $24^{\circ} \mathrm{C}$ in the winter (November-April) and above $27^{\circ} \mathrm{C}$ in the summer (May-October).

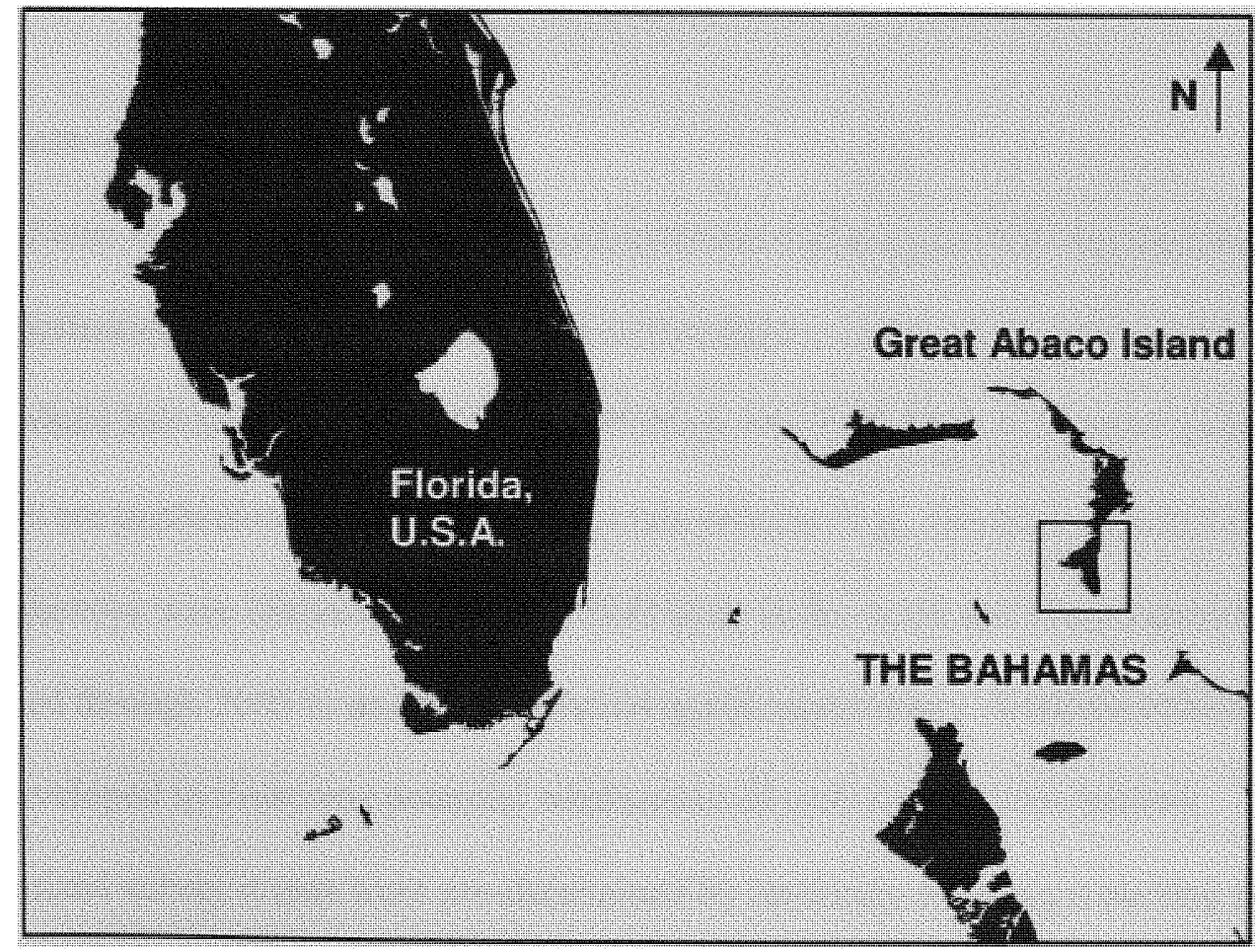

Figure 2: The study was conducted off the southern end of Great Abaco Island, the Bahamas. 


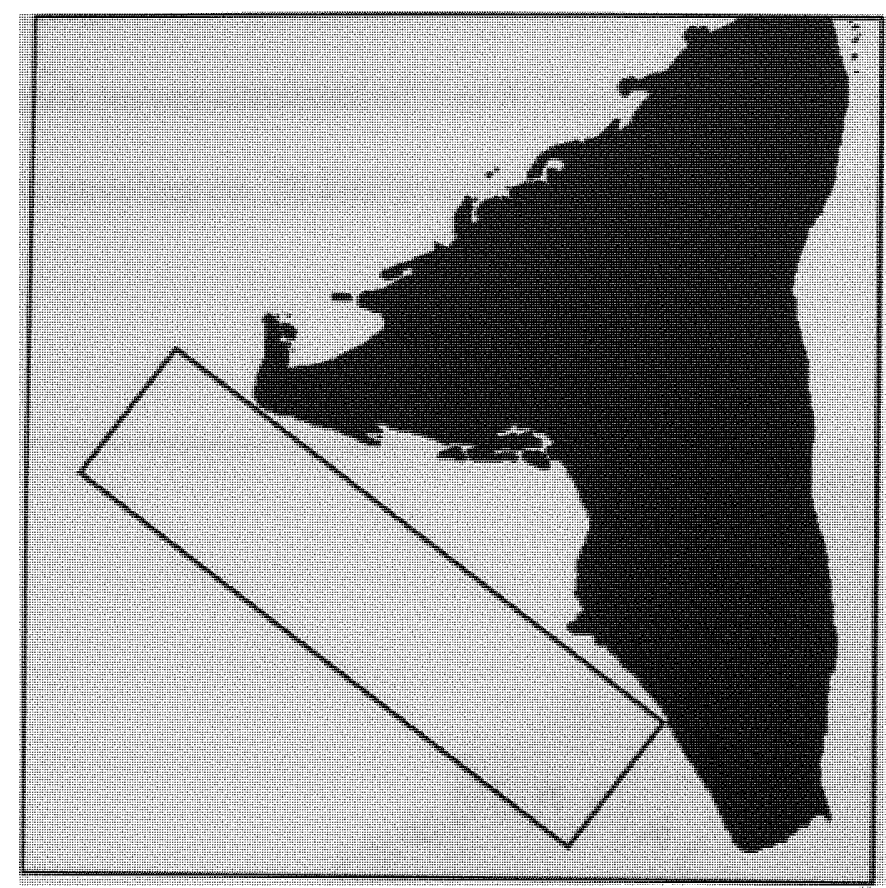

Figure 3. The $6 \times 21 \mathrm{~km}$ study area off southern Great Abaco Island.

\section{Field methods}

From May 2001 to August 2005, randomized equal angle $\left(70^{\circ}\right)$ zigzag surveys and opportunistic surveys were conducted within the $6 \times 21 \mathrm{~km}$ study area to assess dwarf sperm whale habitat use and group size. Although repeated transects parallel to depth contours are preferable for assessing habitat use patterns (e.g., Heithaus and Dill 2002), zigzag surveys were initiated by the BMMRO early in the study and these surveys were continued through 2005 to maintain methodological consistency. Analysis techniques were developed to overcome potential weaknesses of such surveys (see below). Randomized survey routes were pre-determined by randomly selecting a starting position along the southeast end of the study area and an initial heading (NE or SW). The direction in which surveys were run (i.e., from east to west or west to east) was 
determined by lighting and sea conditions at the start of the survey. Depending on the starting position, each survey consisted of 7 or 8 "legs" (Figure 4). Surveys were run in small boats $(<7 \mathrm{~m})$ traveling $c a .28 \mathrm{~km} / \mathrm{hr}$ with observers scanning $180^{\circ}$ to both sides of the vessel.

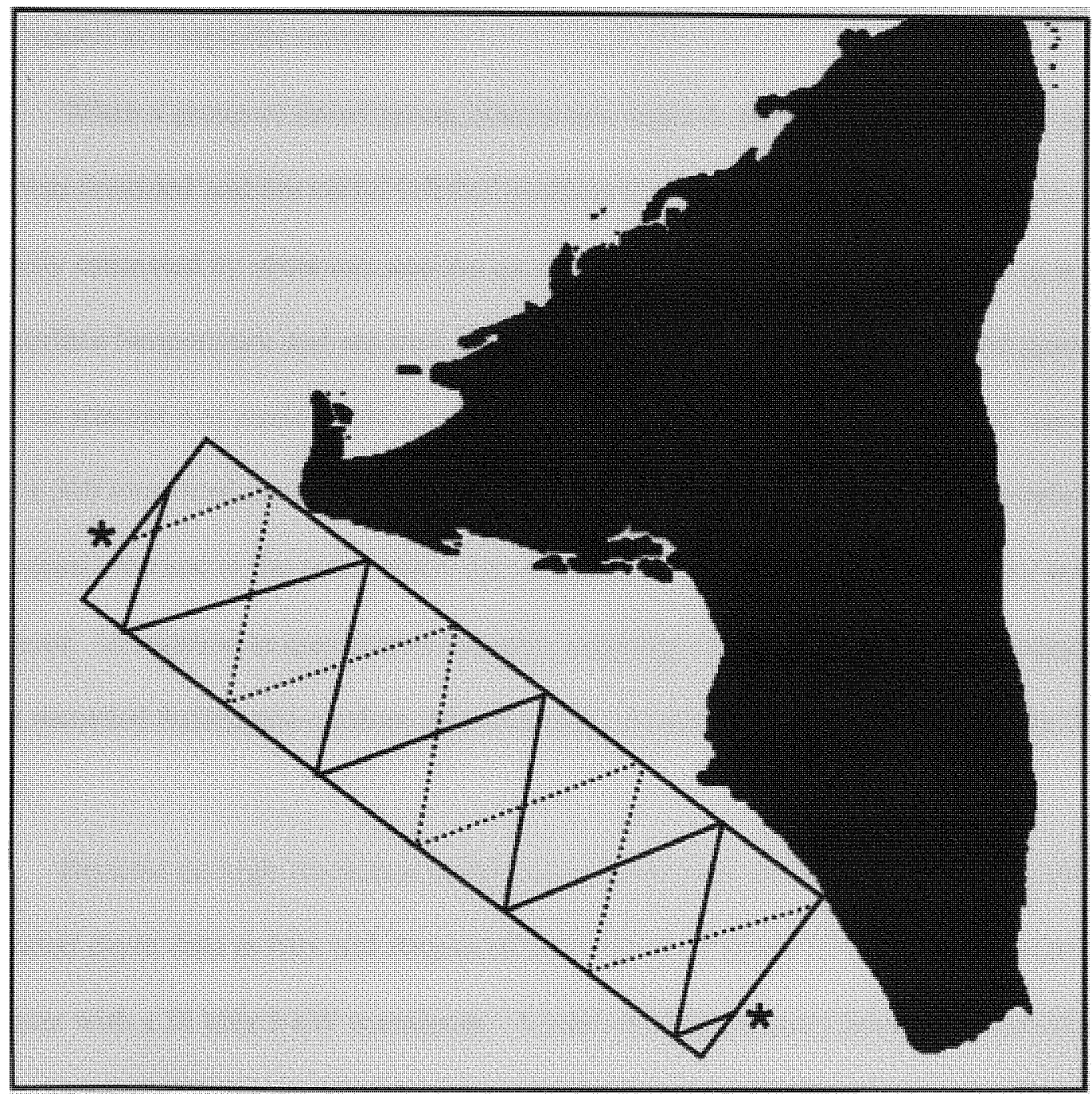

Figure 4. Two examples of randomized zigzag survey tracks. The asterisk indicates the starting position of each example track. 
Beaufort sea state and sea surface temperature were recorded at the beginning and end of each leg, and a Garmin 48 GPS recorded the position of the vessel every minute. No more than one survey was conducted per day; however, in many cases surveys were not completed in a single day. When this occurred, the survey was resumed on a subsequent day at the ending location. For the purposes of analysis (see below), each day was treated as a separate survey.

When a group of dwarf sperm whales was sighted, the GPS position on the survey line was recorded and the vessel left that position to approach the group. Group size was visually estimated by observers and the group's GPS location was recorded, along with sea surface temperature and sea state. To confirm the species identification and group size, an attempt was made to photograph each group member using $35 \mathrm{~mm}$ SLR cameras with a $300 \mathrm{~mm}$ fixed lens or $200-400 \mathrm{~mm}$ zoom lens. Once the sighting was completed, the vessel returned to the point where the survey line was departed and the survey was resumed. In addition to quantitative surveys, sightings of dwarf sperm whale groups were recorded during non-random opportunistic surveys within the study area from 20012005.

Because no high-resolution bathymetry charts were available for the study site, I collected depth data in July and August of 2006 using a Furuno FCV1100 LCD echo sounder with a $28 \mathrm{kHz} 3 \mathrm{~kW}$ transducer. A total of 12 bathymetry transects, each $21 \mathrm{~km}$ long and parallel to the study grid, were spaced $0.5 \mathrm{~km}$ apart within the $6 \times 21 \mathrm{~km}$ grid. Depth and GPS position were recorded every $1 \mathrm{~km}$ along each transect ( $n=264$ points). One-hundred meter and $10 \mathrm{~m}$ bathymetry contours were created using ESRI ArcView GIS 3.2. 
The study area was divided into three habitats based on $100 \mathrm{~m}$ contours and slope of the seafloor: shallow (2-400 m depth), slope (400-900 m depth), and deep (900-1600 $m$ depth) (Figure 5). This division ensured adequate sampling area within each habitat type. The shallow habitat occupies ca. $24 \mathrm{~km}^{2}$ of the study area and most depths are between $2-100 \mathrm{~m}$. The waters of the deep habitat $\left(c a .70 \mathrm{~km}^{2}\right)$ become progressively deeper offshore, but there is less bathymetric relief than in the slope habitat $\left(c a .32 \mathrm{~km}^{2}\right)$. Depths for each dwarf sperm whale encounter within the study area were assigned using $10 \mathrm{~m}$ contours in GIS.

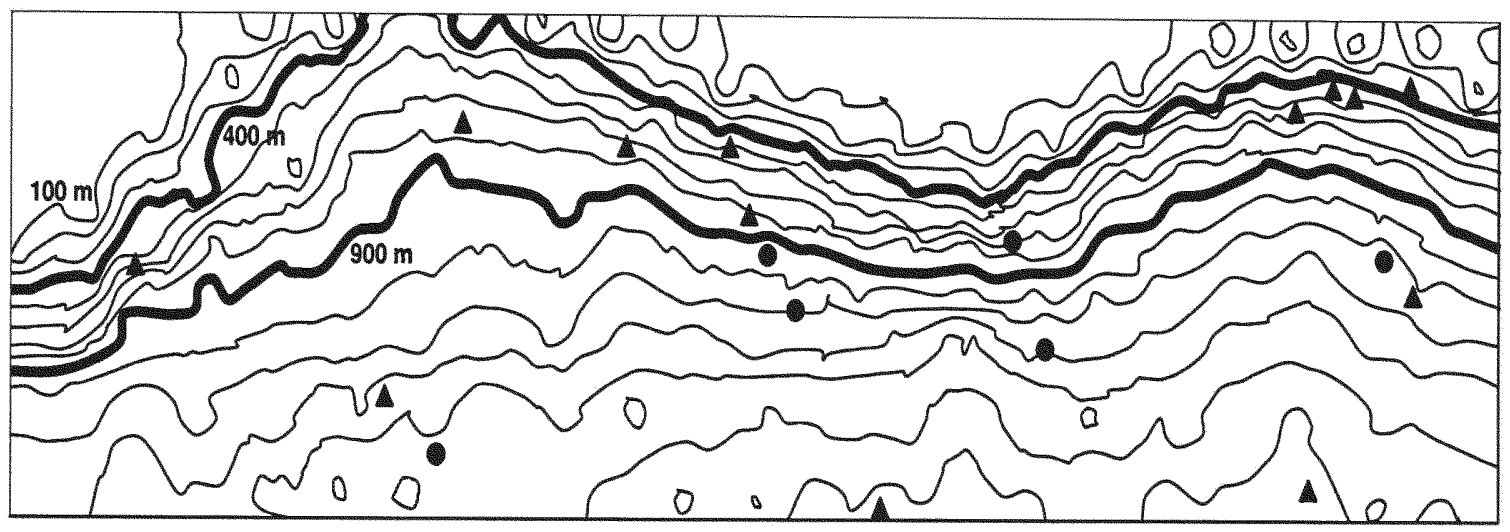

Figure 5. The study area with $100 \mathrm{~m}$ bathymetric contours and dwarf sperm whale sightings during randomized surveys (2001-2005). Habitat boundaries are bold. Circles are dwarf sperm whale sightings during randomized surveys in summer (June-August) and triangles are dwarf sperm whale sightings in winter (JanuaryMarch).

Analysis

Survey tracks were downloaded at the completion of each day. Portions of the track before and after the survey, when the vessel broke the survey line, and during 
cetacean sightings were excluded. Beaufort sea states were assigned to each one-minute GPS position point of the track using the sea state recorded at the beginning and end of a leg. If the sea state changed during a leg, it was assumed that the change occurred at the midpoint of the leg. All GPS one-minute effort points were imported into GIS and counted in each of the three habitats (shallow, slope, deep) for every sampling day. In each day, any habitat that had less than four effort points during appropriate conditions (see below) was excluded from analysis. Only days that sampled all three habitats adequately were used for analysis.

Since dwarf sperm whales are difficult to sight in poor weather conditions and only one dwarf sperm whale sighting occurred in seas greater than Beaufort 2 , the habitat use analysis was restricted to sea states of Beaufort 0,1 , and 2. The mean distance between the location along the transect where a dwarf sperm whale group was sighted and the actual location of the group (measured in GIS) varied with sea state. Distances to groups in Beaufort 1 conditions (mean $=0.633 \mathrm{~km} \pm 0.402 \mathrm{SD}, n=24$ groups) were not significantly different from distances to groups sited in Beaufort 2 conditions (mean = $0.562 \mathrm{~km} \pm 0.424 \mathrm{SD}, n=9 ; t=0.44, \mathrm{df}=31, P=0.66$ ). However, groups were sighted at significantly greater mean distances in Beaufort 0 conditions (mean $=1.138 \mathrm{~km} \pm$ $1.027 \mathrm{SD}, n=14 ; t=2.54, \mathrm{df}=45, P=0.015$ ). Therefore, I corrected for variation in sighting conditions by weighting each GPS one-minute effort point by relative sighting efficiency of the sea state at that point using the $3^{\text {rd }}$ quartile distance for sightings in Beaufort 0 conditions divided by the $3^{\text {rd }}$ quartile distance for sightings in both Beaufort 1 and 2 conditions combined (effort points in Beaufort $0=1$, Beaufort 1 and Beaufort $2=$ 0.51). Beaufort 1 conditions and Beaufort 2 conditions were treated equally for effort 
calculations because they were not statistically different from one another. For each habitat of every survey day, I calculated sightings per unit effort (SPUE) by dividing the number of dwarf sperm whale groups in a habitat by the sum of effort, corrected for sea state, in that habitat.

Because of unequal survey effort across months and years, I restricted my analyses of habitat use to three months in winter (January-March) and summer (JuneAugust) during which effort was consistent across years. I used analysis of variance (ANOVA) to determine whether dwarf sperm whale relative abundance varied by habitat, season, year, and the interactions of these main effects. Habitat, season, and year were treated as fixed effects and SPUE data were square-root transformed to normalize variances. Non-significant interactions $(P>0.10)$ were removed from analysis. I also ran ANOVA with a collapsed data set (with an average SPUE value for each season of each year), but the general results were similar and are not presented here.

Temporal and spatial variation in dwarf sperm whale group size was investigated using both randomized survey data and opportunistic data collected inside the study area during January-March and June-August of 2001-2005. Photographs from dwarf sperm whale encounters were used to confirm field estimates of group size. Group sizes were square-root transformed to normalize the data and ANOVA was used to determine the effect of habitat, season, year, and their interactions (as described above).

Photographs from dwarf sperm whale encounters were examined to confirm group size and identify individuals. Individuals were identified using natural markings on their dorsal fins (e.g., Würsig and Würsig 1977; Figure 6). Animals with unmarked fins can sometimes be distinguished within an encounter but cannot be distinguished 
between encounters. Therefore, to establish the minimum number of animals

photographed, the number of dwarf sperm whales with clean fins and marked fins was determined for each encounter. Identification photographs were assigned a quality grade based on image size, focus, and lighting and only high quality photographs were used for site fidelity analysis.

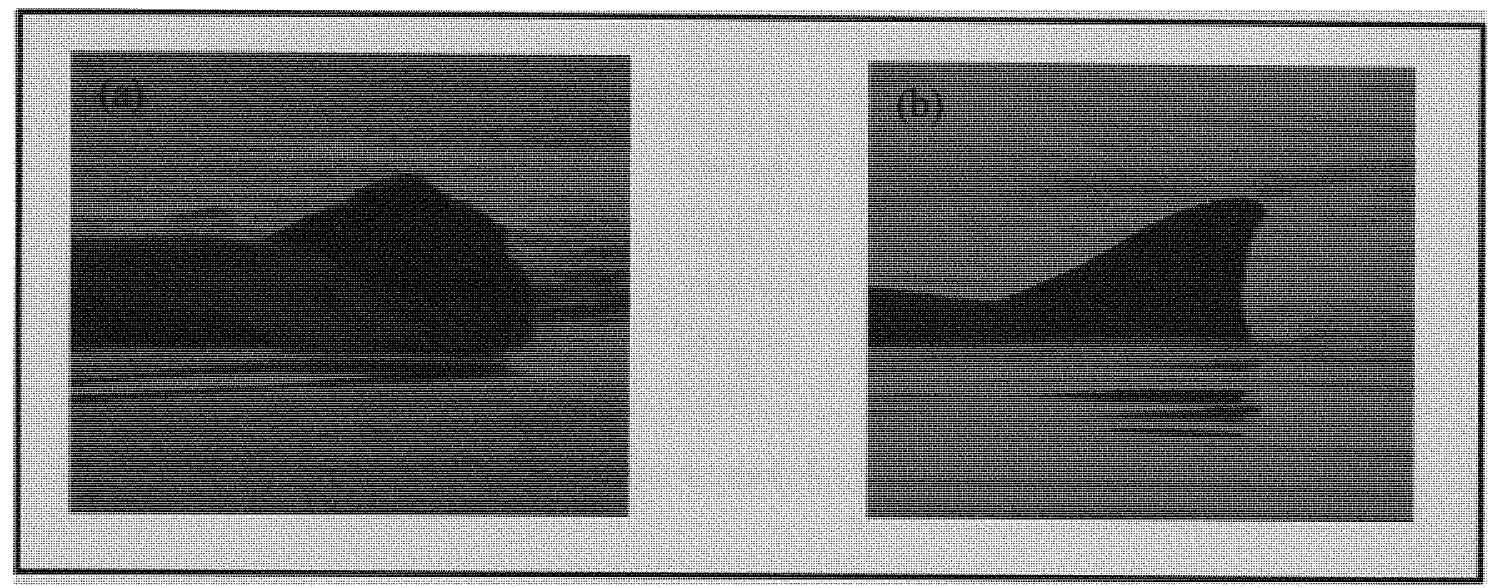

Figure 6. An example of a marked and identifiable dwarf sperm whale dorsal fin (a) and an unmarked and unidentifiable dwarf sperm whale dorsal fin (b).

\subsection{RESULTS}

In total, 70 surveys were conducted across all three habitats for a total of over 107 hours (Table 1). Fifty-four dwarf sperm whale groups were encountered and the mean depth of encounters was $905.4 \mathrm{~m} \pm 49.6 \mathrm{SE}$. Depths of encounters ranged from $302 \mathrm{~m}$ to $1535 \mathrm{~m}$. Of all dwarf sperm whale encounters, 33 sightings occurred during surveys and 19 of these during target months from 2001-2005. Only five groups of pygmy sperm 
whales were encountered from 2001-2005 and the mean depth of encounters was $746.7 \mathrm{~m}$ $\pm 347 \mathrm{SE}$.

Table 1. Survey effort off Great Abaco Island.

\begin{tabular}{lllll}
\hline Habitat & $\begin{array}{l}\text { Area } \\
\left(\mathrm{km}^{2}\right)\end{array}$ & Season & Surveys & Hours \\
\hline Shallow & 24 & Summer & 39 & 14.38 \\
& & Winter & 31 & 13.98 \\
& & Total & 70 & 28.37 \\
\hline Slope & 32 & Summer & 39 & 13.87 \\
& & Winter & 31 & 11.37 \\
& & Total & 70 & 25.23 \\
\hline Deep & 70 & Summer & 39 & 29.20 \\
& & Winter & 31 & 24.48 \\
& & Total & 70 & 53.68 \\
\hline Total & & & 70 & 107.28 \\
\hline \hline
\end{tabular}

Photographs were taken of 216 potential individuals, but only $48(22.2 \%)$ individuals had natural markings that facilitated identification. Seven of these 48 $(18.9 \%)$ individuals were resighted once and two (5.4\%) were resighted twice. Seven individuals were resighted in different years, including one resighted after almost six years.

The number of dwarf sperm whale groups encountered was influenced by an interaction between season and habitat (Table 2; Figure 7). During summer, dwarf sperm whale relative abundances were generally low. In winter, the overall sighting rate increased but primarily in the slope habitat, where sighting rates were almost six times 
higher than in the shallow or deep habitats. Sighting rates did not vary significantly across years.

Table 2. ANOVA table of dwarf sperm whale habitat use.

\begin{tabular}{llll}
\hline Factor & $\mathrm{df}$ & $F$ & $P$ \\
\hline Year & 4,379 & 1.24 & 0.30 \\
Season & 1,379 & 5.75 & 0.017 \\
Habitat & 2,379 & 4.75 & 0.009 \\
Season x habitat & 2,379 & 4.67 & 0.010 \\
\hline \hline
\end{tabular}

In general, dwarf sperm whales were found in small groups (median $=3$, range $=$ $1-12, n=54$ groups), but groups were significantly larger in winter (median $=4$, range $=$ $1-12, n=20$ groups) than in summer (median $=2.5$, range $=1-8, n=34$ groups) (Table 3 ; Figure 8). Group size did not vary with habitat and differences in group size among years were marginally significant (Table 3; Figure 9). 


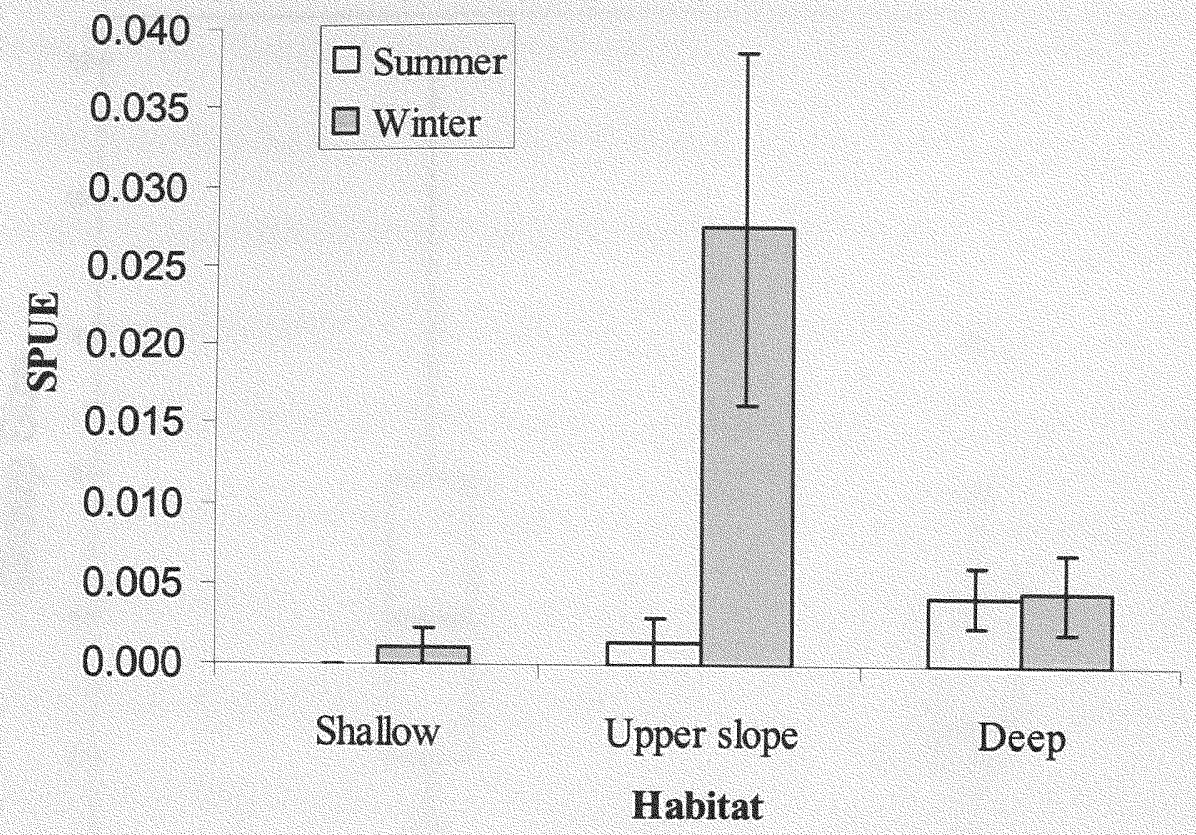

Figure 7. Spatial and temporal variation in dwarf sperm whale sightings per unit effort (SPUE) during randomized surveys. Units of effort are GPS one-minute effort points weighted by relative sighting efficiency in the sea state at that time. Error bars are $\pm \mathrm{SE}$.

Table 3. ANOVA table of dwarf sperm whale group size.

\begin{tabular}{llll}
\hline \hline Factor & df & $F$ & $P$ \\
\hline Year & 4,53 & 2.56 & 0.053 \\
Season & 1,53 & 8.36 & 0.006 \\
Habitat & 2,53 & 0.40 & 0.67 \\
Season x habitat & 2,53 & 0.52 & $0.60^{*}$ \\
\hline \hline
\end{tabular}

*Removed from final model. 


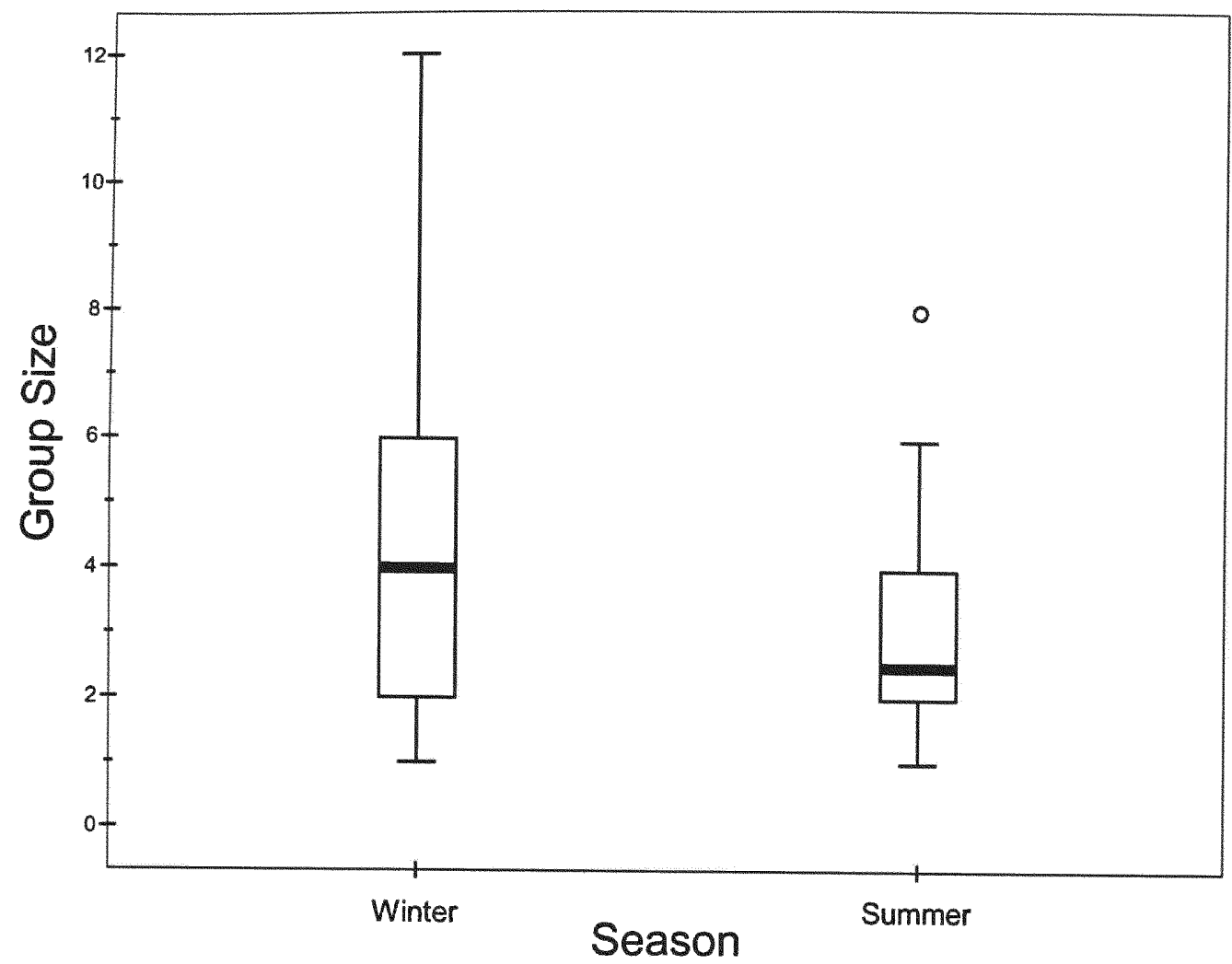

Figure 8. Seasonal variation in dwarf sperm whale group size. Thick bars represent the median, outside borders represent the $1^{\text {st }}$ and $3^{\text {rd }}$ quartile, error bars represent the range, and circles represent outliers.

\subsection{DISCUSSION}

Dwarf sperm whales are considered to be a pelagic species of the continental shelf and slope (see Willis and Baird 1998), but their specific habitat affinities have been poorly understood. I found that dwarf sperm whales were always found in waters deeper than $300 \mathrm{~m}$ and were distributed primarily along the upper canyon slope. However, dwarf sperm whale habitat use varied seasonally. During summer, dwarf sperm whale group sizes were small and sighting rates were low and spread relatively evenly among 
deeper habitats. In winter, groups were larger and encounter rates increased, primarily in the slope habitat. Together, these results suggest net movement of individuals into the study area, possibly because of seasonal onshore-offshore movements, with most individuals found offshore and beyond the study area in summer. Future studies should include surveys that extend further offshore to assess this possibility.

Previous studies have presented two different views of dwarf sperm whale habitat use - one of a relatively nearshore species and one of an offshore, pelagic species. MacLeod et al. (2004) reported that the mean depth of ten dwarf sperm whale sightings off the east side of Great Abaco Island, the Bahamas was $247 \mathrm{~m}$. In contrast, Baird (2005) recorded dwarf sperm whale sightings in much deeper waters off of Hawaii (mean $=1565 \mathrm{~m} \pm 1017 \mathrm{SD})$, and never in waters less than $450 \mathrm{~m}$.

Despite the close proximity $(\mathrm{ca} .100 \mathrm{~km})$ of my study site to that of McLeod et al. (2004), I found dwarf sperm whale groups at a mean depth more than three times greater $(905 \mathrm{~m})$ and did not encounter groups in less than $300 \mathrm{~m}$. This discrepancy in the mean depths over a relatively small spatial scale is surprising. However, differences may be associated with variation in sampling methods. First, I found that topographic maps, like those used by MacLeod et al. (2004) did not provide accurate depth data in my study area for fine-scale habitat use analysis. Second, my surveys were designed to sample depths in proportion to their availability and were conducted across seasons, while those off the east coast of Great Abaco Island were non-random, conducted only in summer months, and thus are of limited value for cross-site comparisons (MacLeod et al. 2004).

Future studies need to consider the effect of sea state on sighting efficiency and should strive to sample all accessible depths across seasons. By accounting for effort 
(weighted by sighting biases) and examining the effect of season on habitat use, I found that dwarf sperm whales may occupy offshore habitats in the summer season and move into the slope region and shallow depths with higher relief during the winter season.

Physical features besides water depth likely make the slope habitat attractive to dwarf sperm whales. High relief, a sloping canyon wall, and other oceanographic features and processes may physically aggregate prey (Moser and Smith 1993, Logerwell and Smith 2001), although the small group sizes of dwarf sperm whales suggest that their prey probably do not occur in high densities. Alternatively, high relief areas provide structures on which to herd prey or may produce currents that reduce energetic costs of foraging in that area (e.g., Williams et al. 1996), both of which can increase the foraging efficiency of predators (Croxall et al. 1985). These mechanisms may explain the common association of cetaceans with high-relief habitats (e.g., sperm whales, Jaquet and Whitehead 1996; northern bottlenose whales, Hooker et al. 2002; bottlenose dolphins, Tursiops truncatus, Hastie et al. 2003), and may make the slope a high quality habitat for dwarf sperm whales.

Habitat use patterns of cetaceans have also been linked to changes in prey abundance (e.g., sperm whales, Jaquet et al. 2000; bottlenose dolphins, T. aduncus, Heithaus and Dill 2002, 2006; humpback and minke whales, Friedlaender et al. 2006). Therefore, variation in the abundance and distribution of prey may drive the seasonal influx of dwarf sperm whales into the study area. Squid are common prey of dwarf sperm whales in the Caribbean (Cardonna-Maldonado and Mignucci-Giannoni 1999), so seasonal movements of squid could cause inshore shifts in dwarf sperm whales. Although no data exist for the Bahamas, in other areas squid move inshore and into areas 
of high bathymetric relief in winter. For example, schoolmaster gonate squid (Berryteuthis magister) in the Bering Sea are found in low concentrations in the summer but aggregate over the continental slope in the winter (Arkhipkin et al. 1996). Similarly, in northwest Africa, mature European flying squid (Todarodes sagittatus) move to continental slopes to spawn in winter months (Arkhipkin et al. 1999).

Seasonal changes in dwarf sperm whale habitat use and group size may be influenced by factors other than the distribution or abundance of their prey. Predation risk (Lima and Dill 1990), interspecific competition (e.g., Robertson 1996), and reproductive and social behavior (e.g., Stamps 1991) all may influence habitat use and group size. For example, bottlenose dolphins in Australia shift from productive but risky shallow habitats to safer, deeper waters and increase group size when predatory tiger sharks (Galeocerdo cuvier) are present (Heithaus and Dill 2002).

Dwarf sperm whales are at risk from killer whales (Orcinus orca) (Jefferson et al. 1991) and sharks (Willis and Baird 1998, Heithaus 2001). Killer whales were observed attacking dwarf sperm whales in the study area in 2001 and 2005 (Figure 9), but they have only been encountered twice in the study area since 1997. Both encounters were during summer (BMMRO, unpublished data). It is possible that by occurring in smaller groups and occupying deeper habitats in summer, dwarf sperm whales are able to avoid detection by killer whales. 


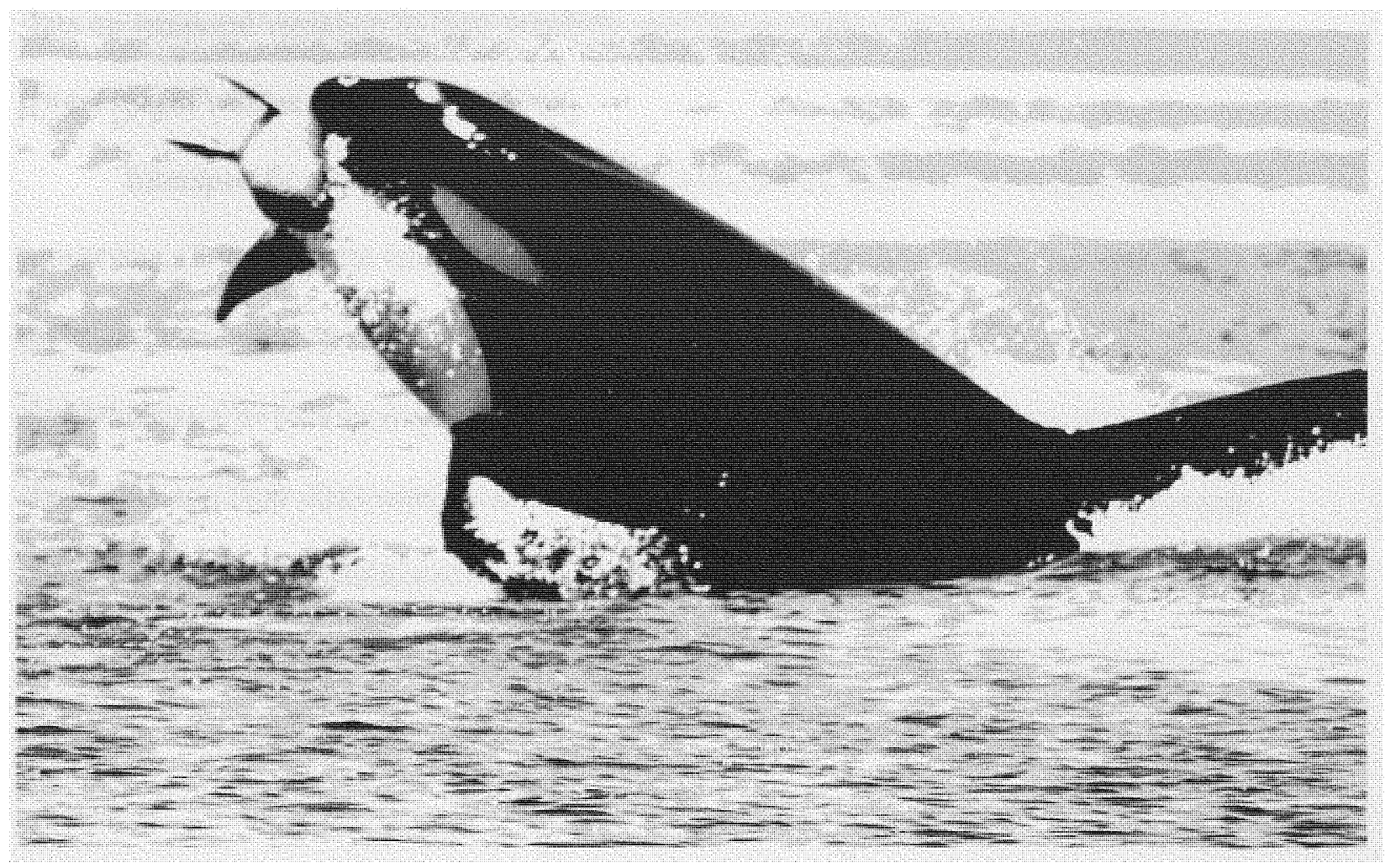

Figure 9. Killer whale attack on a dwarf sperm whale in the study area off of Great Abaco Island, the Bahamas on 27 July 2005.

Although the threat of shark predation to dwarf sperm whales is often overlooked, parasites found in stranded individuals suggest that attacks may be more common than generally appreciated (see Gibson et al. 1998, Walker 2001, Anzar 2007). Sharks are the final host for larval cestodes (Cheung 1993, Caira and Healy 2004), such as Phyllobothrium delphini, that are commonly found encysted in dwarf sperm whale blubber (Nagorsen 1985, Cardonna-Maldonado and Mignucci-Giannoni 1999, Goold and Clarke 2000). In order for these parasites to be transmitted, shark predation and scavenging of dwarf sperm whale carcasses must be relatively frequent. Tiger sharks, 
which are a major cetacean predator (Heithaus 2001), are present in the study area and could influence dwarf sperm whale habitat use and group size. However, there are no data on temporal variation in their numbers, and the possible effects of predation on dwarf sperm whales remain speculative.

Interspecific competition may also influence dwarf sperm whale habitat use and group size. Dwarf sperm whales are the most frequently encountered oceanic species in the study area (Claridge 2006), but pygmy sperm whales, Blainville's beaked whales ( $M$. densirostris), Cuvier's beaked whales, and sperm whales are also encountered in the study area and their diets overlap somewhat with that of dwarf sperm whales (Willis and Baird 1998, Cardona-Maldonado and Mignucci-Giannoni 1999). Seasonal and spatial trends in the abundance of species other than dwarf sperm whales need to be determined in order to understand the potential influence of interspecific competition on dwarf sperm whales.

Finally, social behavior and reproductive considerations may influence habitat use and group sizes of dwarf sperm whales. Little is known about sociality in dwarf sperm whales, largely because of the difficulties in identifying individuals at sea, which is critical for determining social structure (e.g., Whitehead 1997). Although individual identification of this species is difficult due to their small size and propensity to avoid close approaches by boats (Willis and Baird 1998), Baird et al. (2006) were able to recognize individual dwarf sperm whales in eight out of ten encounters in Hawaii. The majority of dwarf sperm whales photographed $(78 \%)$ in our study area did not have marked dorsal fins, making identification impossible. Nonetheless, we resighted nine of 48 identifiable individuals including one resighting after over five years, suggesting some 
individuals remain in the study area or return seasonally. Therefore, dedicated photoidentification efforts may help to elucidate dwarf sperm whale social behavior and reproductive ecology, but other techniques (e.g., genetic sampling) may prove more useful.

Pelagic and small-bodied cetaceans often are found in large groups of dozens to hundreds of individuals (e.g., pantropical spotted dolphin, S. attenuata; spinner dolphin, S. longirostris; short-beaked common dolphin, Delphinus delphis; see Scott and Cattanach 1998) which likely function to dilute the risk of predation (see Heithaus 2001 for a review). It is therefore somewhat surprising that dwarf sperm whale group sizes are small in the Bahamas (median $=3.46)$ and off of Hawaii (mean $=2.33$, Baird 2005). The presence of small groups in such apparently high-risk open habitats likely is driven by relatively low food densities prohibiting the formation of large groups (e.g., Bertram 1978). Thus, further studies of dwarf sperm whales that integrate data on predator abundance and prey availability may provide insights into the relative roles of predation risk and foraging ecology on the evolution of group living and social structure on pelagic cetaceans. 


\section{LITERATURE CITED}

Anzar, F.J., C. Agusti, D.T.J. Littlewood, J.A. Raga, and P.D. Olson. 2007. Insight into the role of cetaceans in the life cycle of the tetraphyllideans (Platyhelminthes: Cestoda). International Journal for Parasitology 37:243-255.

Arkhipkin, A.I., V.A. Bizikov, V.V. Kryloy, and K.N. Nesis. 1996. Distribution, stock structure, and growth of the squid Berryteuthis magister (Berry, 1913) (Cephalopoda, Gonatidae) during summer and fall in the western Bering Sea. Fishery Bulletin 94:1-30.

Arkhipkin, A.I., V. Laptikhovsky, and A. Golub. 1999. Population structure and growth of the squid Todarodes sagittatus (Cephalopoda: Ommastrephidae) in north-west African waters. Journal of Marine Biological Association of the United Kingdom 79: 467 .

Baird, R.W. 2005. Sightings of dwarf (Kogia sima) and pygmy (K. breviceps) sperm whales from the main Hawaiian Islands. Pacific Science 59:461-466.

Baird, R.W., G.S. Schorr, D.L. Webster, D.J. McSweeney, and S.D. Mahaffy. 2006. Studies of beaked whale diving behavior and odontocete stock structure in Hawai'i in March/April 2006. Report prepared under contract No. AB133F-06$\mathrm{CN}-0053$ to Cascadia Research from the Southwest Fisheries Science Center, NMFS, La Jolla, CA.

Balcomb, K.C. and D.E. Claridge. 2001. A mass stranding of cetaceans caused by naval sonar in the Bahamas. Bahamas Journal of Science 5:2-12.

Barlow, J., and R. Gisner. 2006. Mitigating, monitoring, and assessing the effects of anthropogenic sound on beaked whales. Journal of Cetacean Research and Management 7:239-249.

Baumgartner, M.F., K.D. Mullin, and L.N. May. 2001. Cetacean habitats in the northern Gulf of Mexico. Fishery Bulletin 99:219-239.

Bertram, B. C. R. 1978. Living in Groups: Predators and Prey. Pages 64-96 in J. R. Krebs and N. B. Davies, eds. Behavioural Ecology: An Evolutionary Approach. Blackwell, Oxford.

Caira, J.N. and C.J. Healy. 2004. Elasmobranchs as hosts of Metazoan parasites. Pages 524-551 in J.C. Carrier, J.A. Musick, and M.R. Heithaus, eds. Biology of Sharks and Their Relatives. CRC Press, Boca Raton, Florida. 
Caldwell, D.K. and M.C. Caldwell. 1989. Pygmy sperm whale Kogia breviceps (de Blainville, 1838): dwarf sperm whale Kogia simus Owen, 1866. Pages 235-260 in S.H. Ridgway and Sir R. Harrison, eds. Handbook of Marine Mammals Volume 4: River Dolphins the Larger Toothed Whales. Academic Press, London.

Caldwell, D.K., H. Neuhauser, M.C. Caldwell, and H.W. Coolidge. 1971. Recent records of marine mammals from the coasts of Georgia and South Carolina. Cetology 5:112.

Cardona-Maldonado, M.A., and A.A. Mignucci-Giannoni. 1999. Pygmy and dwarf sperm whales in Puerto Rico and the Virgin Islands, with a review of Kogia in the Caribbean. Caribbean Journal of Science 35:29-37.

Cheung, P. 1993. Parasitic diseases of elasmobranchs. Pages 782-807 in M.K. Stoskopf, eds. Fish Medicine. W.B. Saunders, Philadelphia.

Claridge, D.E. 2006. Fine-scale distribution and habitat selection of beaked whales. M.Sc. Thesis, University of Aberdeen, Scotland, U.K. 127 pp.

Croxall, J.P., I. Everson, G.L. Kooyman, C. Ricketts, R.W. Davis. 1985. Fur seal diving behavior in relation to vertical distribution. Journal of Animal Ecology 54:1-8.

Fernández, A., J.F. Edwards, F. Rodríguez, A. Espinosa de los Monteros, P. Herráez, P. Castro, J.R. Jaber, V. Martín, and M. Arbelo. 2005. "Gas and fat embolic syndrome" involving a mass stranding of beaked whales (Family Ziphiidae) exposed to anthropogenic sonar signals. Veterinary Pathology 42:446-457.

Frantzis, A. 1998. Does acoustic testing strand whales? Nature 392:29.

Friedlaender, A.S., P.N. Haplin, S.S. Qian G.L. Lawson, P.H. Wiebe, D. Thiele, and A.J. Read. 2006. Whale distribution in relation to prey abundance and oceanographic processes in shelf waters of the Western Antarctic Peninsula. Marine Ecology Progress Series 317:297-310.

Gibson, D.I., E.A. Harris, R.A. Bray, P.D. Jepson, T. Kuiken, J.R. Baker, and V.R. Simpson. 1998. A survey of the helminth parasites of cetaceans stranded on the coast of England and Wales during the period of 1990-1994. Journal of Zoology 244:563-574.

Goold, J.C., and M.R. Clarke. 2000. Sound velocity in the head of the dwarf sperm whale, Kogia sima, with anatomical and functional discussion. Journal of the Marine Biological Association of the United Kingdom 80:535-542. 
Handley, C.O., Jr. 1966. A synopsis of the genus Kogia (pygmy sperm whales). Pages 63-69 in K. Norris, ed. Whales, Dolphins, and Porpoises. University of California Press, Berkeley, California.

Hastie, G.D., B. Wilson, and P.M. Thompson. 2003. Fine-scale habitat selection by coastal bottlenose dolphins: application of a new land-based video-montage technique. Canadian Journal of Zoology 81:469-478.

Heithaus, M.R. 2001. Predator-prey and competitive interactions between sharks (order Selachii) and dolphins (suborder Odontoceti): a review. Journal of Zoology 253:53-68.

Heithaus, M.R. and L.M. Dill. 2002. Food availability and tiger shark predation risk influence bottlenose dolphin habitat use. Ecology 83:480-491.

Heithaus, M.R. and L.M. Dill. 2006. Does tiger shark predation risk influence foraging habitat use by bottlenose dolphins at multiple spatial scales? Oikos 114:257-264.

Hooker, S.K., H. Whitehead, S. Gowans, and R.W. Baird. 2002. Fluctuations in distribution and patterns of individual range use of northern bottlenose whales. Marine Ecology Progress Series 225:287-297.

Jaquet, N. and H. Whitehead. 1996. Scale-dependent correlation of sperm whale distribution with environmental features and productivity in the South Pacific. Marine Ecology Progress Series 135:1-9.

Jaquet, N., S. Dawson, and E. Slooten. 2000. Seasonal distribution and diving behavior of male sperm whales off Kaikoura: foraging implications. Canadian Journal of Zoology 78:407-419.

Jefferson, T.A., P. J. Stacey, and R.W. Baird. 1991. A review of killer whale interactions with other marine mammals: Predation to co-existence. Mammal Review 21:151180.

Jepson, P.D., M. Arbelo, R. Deaville, I.A.P. Pattersone, P. Castro, J.R. Baker, E. Degollada, H.M. Ross, P. Herráez, A.M. Pocknell, F. Rodríguez, F.E. Howie, A. Espinosa, R.J. Reid, J.R. Jaber, V. Martin, A.A. Cunningham, and A. Fernández. 2003. Gas-bubble lesions in stranded cetaceans: Was sonar responsible for a spate of whale deaths after an Atlantic military exercise? Nature 425:575-576.

Lima, S.L. and L.M. Dill. 1990. Behavioral decisions made under the risk of predation: a review and prospectus. Canadian Journal of Zoology 68:619-640.

Logerwell, E.A. and P.E. Smith. 2001. Mesoscale eddies and survival of late stage Pacific sardine (Sardinops sagax) larvae. Fisheries Oceanography 10:13-25. 
MacLeod, C.D., and A. D'Amico. 2006. A review of beaked whale behaviour and ecology in relation to assessing and mitigating impacts of anthropogenic noise. Journal of Cetacean Research and Management 7:211-221.

MacLeod, C.D., N. Hauser, and H. Peckham. 2004. Diversity, relative density and structure of the cetacean community in southern months east of Great Abaco, Bahamas. Journal of the Marine Biological Association of the United Kingdom 84:469-474.

Manire, C.A., H.L. Rhinehart, N.B. Barros, L. Byrd, and P. Cunningham-Smith. 2004. An approach to the rehabilitation of Kogia spp. Aquatic Mammals 30:257-270.

McAlpine, D.F. 2002. Pygmy and dwarf sperm whales Kogia breviceps and K. sima. Pages 1007-1009 in W. F. Perrin, B.Würsig, and J. G. M. Thewissen, eds. Encyclopedia of marine mammals. Academic Press, San Diego.

Moser, H.G. and P.E. Smith. 1993. Larval fish assemblages and oceanic boundaries. Bulletin of Marine Science 53:283-289.

Nagorsen, D.W. 1985. Kogia simus. Mammalian Species 239:1-6.

Read, A.J and P.R. Wade. 2000. Status of marine mammals in the United States. Conservation Biology 14: 929-940.

Robertson, D.R. 1996. Interspecific competition controls abundance and habitat use of territorial Caribbean damselfishes. Ecology 77:885-899.

Scott, M.D. and K.L. Cattanach. 1998. Diel patterns in aggregations of pelagic dolphins and tunas in the eastern pacific. Marine Mammal Science 14:401-428.

Stamps, J.A. 1991. The effect of conspecifics on habitat selection in territorial species. Behavioral Ecology and Sociobiology 28:29-36.

Walker, W.A. 2001. Geographical variation of the parasite, Phyllobothrium delphini (Cestoda), in Dall's porpoise, Phocoenoides dalli, in the Northern North Pacific, Bering Sea, and Sea of Okhotsk. Marine Mammal Science 17:264-275.

Whitehead, H. 1996. Variation in the feeding success of sperm whales: temporal scale, spatial scale and relationship to migrations. The Journal of Animal Ecology $65: 429-438$.

Whitehead, H. 1997. Analysing animal social structure. Animal Behaviour 53:1053-1067. 
Williams, T.M., S.F. Shippe, and M.J. Rothe. 1996. Strategies for reducing foraging costs in dolphins. Pages 4-9 in S.P.R. Greenstreet and M.L. Tasker, eds. Aquatic predators and their Prey. Fishing News Books, Oxford.

Willis, P.M., and R.W. Baird. 1998. Status of the dwarf sperm whale, Kogia simus, with special reference to Canada. Canadian Field-Naturalist 112:114-125.

Würsig, B. and M. Würsig. 1977. The photographic determination of group size, composition, and stability of coastal porpoises (Tursiops truncatus). Science 198:775-756. 